\title{
The Entwinement of Religion and Economics: Comments on Bradley Bateman's "In a Space of Questions"
}

\author{
Barbara Herrnstein Smith
}

It has always been hard, it seems, to keep the moneychangers out of the temple or to say exactly where the temple steps end and the marketplace begins. Comparably close and ambiguous are the relations between religion and political economy. In his contribution to this symposium, Bradley Bateman traces what he sees as a fertile "entwine[ment]" of religion and economics in the eighteenth century, an unfortunate separation of them in the nineteenth century, a perilous extirpation of religious understandings from economic models in the twentieth century, and, he hopes, a return to the close relation of the two in the twenty-first century. I share many of Professor Bateman's concerns and find his story instructive, but would like to note some historical, psychological, and normative complexities and to register skepticism on a few points.

Many scholars and scientists maintain that the link between economics and religion is even more ancient and fundamental than Professor Bateman suggests. Nietzsche, for example, in his Genealogy of Morals, traces a number of central moral and religious concepts, including justice, punishment, sacrifice, and redemption, to the structure and dynamics of basic economic relations, notably those between buyer and seller and donor and debtor. ${ }^{1}$ His views are updated and elaborated in an illuminating book,

Correspondence may be addressed to Barbara Herrnstein Smith, Duke University Literature Program, Duke University, Box 90015, Durham, NC 27708-0015.

1. See especially the Second Essay.

History of Political Economy 43:2 DOI 10.1215/00182702-1257514

Copyright 2011 by Duke University Press 
Creation of the Sacred: Tracks of Biology in Early Religions, by the German classicist Walter Burkert. For Burkert, a scholar of ancient civilizations who invokes evolutionary biology, primatology, and game theory along with works by such social theorists as Marcel Mauss, Karl Polanyi, and Pierre Bourdieu, the connection between economics and religion is especially evident in the uniquely human capacity for gift-exchangewhich, he observes, has figured as a fundamental principle of human social relations and religious practices from prehistoric times to the present. Thus he cites a votive inscription on a statuette of Apollo dating from the seventh century BC that reads "Mantiklos has dedicated me to the farshooting god from a tenth of his profit; [may] you, Phoebus, give pleasing return" (Burkert 1996, 129). The principle of reciprocity ("do ut des," I give so that you give) is not only, Burkert observes, a generally successful strategy for dealing with human partners but has also been a sufficiently effective strategy for dealing with gods to survive to later times. Thus he also cites an early Christian inscription stating that a certain benefactor has adorned a church "for release from his sins and remission for those who have died." Burkert comments: "The donor of this expensive gift wants to use it both to pay up his debts and to make an investment, reflecting the double aspect of giving something up and getting something back in return" (154). He notes that Jesus said, "To give is more blessed than to receive." "But," Burkert adds, "the Christian tradition has more or less succeeded in restoring retributive justice and [an] economy of exchange" to the center of its religious teaching (138). As understood by Nietzsche, Burkert, and other naturalistic scholars of religion, then, the entanglement of economics and religion is older than in Professor Bateman's story and deeper than he allows.

Professor Bateman observes that the simplistic understandings of human behavior that currently prevail in mainstream economics are challenged by the work of behavioral economists, and he hopes those understandings will ultimately be revolutionized by the findings of such economists. He takes heart especially from the fact that the players in so-called ultimatum games often reject offers of money that they think are less than fair. In Professor Bateman's view, these exhibitions of the triumph of indignation over avarice support the argument-made by, among others, some contemporary theologians - that humans are characteristically on a quest not for wealth or happiness but for a moral framework that will orient the meaning and purpose of their lives. And, he hopes, the establishment of the existence of such a fundamental aspect of human behavior by 
fellow economists may encourage other economists to give due quarter to religious ideas in their understanding of human behavior.

It is possible, however, to draw rather different lessons about human nature from how we play ultimatum games. For example, one could see the behavior of the money-rejecters as illustrating the satisfaction that humans can take in inflicting pain on people they feel have insulted them, even when it involves considerable cost to themselves. (If one player rejects the other's offer of a meager portion of the money received, neither player, we recall, gets to keep any.) This capacity for spite impressed Dostoevsky as well as Nietzsche and was, for the former, a sign of the nonutilitarianthus animal-transcending, thus to be prized-perversity of human nature. ${ }^{2}$ More recently, such capacities and related behaviors have been explained in specifically biological terms by behavioral ecologists and evolutionary psychologists. Humans living in social groups, they maintain, are innately disposed to punish cheaters, freeloaders, and resource-hoarders even when it involves some cost to themselves, and scenarios have been produced for the evolution of such aggressive dispositions based on the ultimate survival-advantage they would have afforded to our Paleolithic ancestors. ${ }^{3}$

Questions can be raised about the plausibility of some of these scenarios, especially their extensive assumptions regarding the prehistoric conditions of human life and their neglect of the historical, cultural, and individual development of post-Paleolithic humans. ${ }^{4}$ My point here, however, is not that these evolutionary accounts are correct. It is, rather, that the views of human nature currently emerging from the behavioral sciencesevolutionary psychology, cognitive anthropology, behavioral ecology, and so forth-are at some variance from the more morally elevated views of "what it means to be human" that Professor Bateman finds articulated in the writings of theologian Charles Taylor. There is, of course, an irony here. Professor Bateman looks to behavioral economics for evidence about human nature to support his view that religion should have a more central place in economics and thereby displace the unedifying conception of man as simply homo economicus. The major conclusion emerging from the behavioral laboratories, however (as well as from the historical archives), seems to be that homo religiosus does not transcend homo

2. See Dostoevsky's Notes from Underground ([1863] 2004), which was provoked by, among other things, the utilitarian-socialist-utopian novel What Is to Be Done? ([1863] 1989) by Nikolai Chernyshevsky.

3. See Dubreuil 2008 and Boyd, Gintis, and Bowles 2010.

4. For discussion of such problems, see Smith 2009, 130-52. 
economicus but only expresses and extends him, and that our instincts (such as they are) owe as much, and perhaps more, to the residues of our evolutionary history as to what Professor Bateman suggests is (in Kant's words) the moral law within. ${ }^{5}$

The types of sentiments and impulses that Professor Bateman evokes via the writings of Taylor and the poetry of Wisława Szymborska are certainly commendable: a revulsion at the idea of torture; a conviction that some things, such as justice and fairness, should matter more than individual utility-optimizing; a recognition that not everything that humans value can be rendered in monetary terms. It is not clear, however, why such sentiments or impulses should be thought of as specifically religious as distinct from civilized, humanistic, or ethically enlightened. The same can be said for the types of considerations that Professor Bateman mentions as deserving a more central role in economic analyses. While it is no doubt true that people's preferences involve a wide range of values that are not readily measurable by a money metric, such values are not always especially moral and certainly not always specifically religious. They may be, for example, aesthetic or personally sentimental, and they may involve a sense of altogether secular (for example, nationalistic) honor, political loyalty, or social propriety. God and Mammon are not the only alternatives. They are not the only objects, sources, or grounds of what Professor Bateman calls deeper human valuation and they should not, I think, be seen as the only alternatives on which to base economic analyses.

It would be wonderful, I agree, if economists routinely figured social justice into their cost-benefit analyses and took long-range communal and environmental considerations into account in making their comparisons, estimates, and recommendations. But I am not sure how economists would go about persuading their clients (banks, businesses, government budget offices, and so forth) that this sort of ethically enlightened economic analysis was what the latter wanted or, for that matter, how they could persuade various segments of the general public that it was not just socialism or elitism-or, if framed and justified in specifically religious terms, that it was not just theocracy.

5. "Two things fill the mind with ever new and increasing admiration and reverence, the more often and more steadily one reflects on them: the starry heavens above me and the moral law within me. . . the moral law reveals to me a life independent of animality and even of the whole sensible world, at least so far as this may be inferred from the purposive determination of my existence by this law, a determination not restricted to the conditions and boundaries of this life but reaching into the infinite" (Kant [1788] 1997, 133-34). 
Indeed, there is a troublesome ambiguity in Professor Bateman's references to economists taking "religious beliefs" or "religious ideas" into account in their analyses and policy recommendations. It would be one thing for them to register the empirically well-established fact that people's religious beliefs influence their valuations and choices. It would be quite another for them to make policy recommendations on the basis of specifically theistic, theological, or scripturally validated ideas. The first, I would imagine, is standard economic practice where it appears relevant (for example, in figuring out the best location to exhibit a certain film or how to pitch a certain product for sale among different groups) and, in any case, sounds too instrumental to be what Professor Bateman has in mind. So I wonder if what he seeks is a revolution in political economy that would end with the second, that is, with economists constructing models, doing calculations, and making recommendations on the basis of religious ideas. If so, then the question clearly becomes whose ideas they would consult and which ones. For, of course, there are many nominally religious ideas around, and not all of them-even among American economistsare altogether benign, humane, or desirable for all concerned.

So I am inclined to be wary of proposals for a greater entwinement of religion with economics. Indeed, I think there are good reasons for maintaining a wall of separation between them-pretty much the same as the reasons for maintaining a wall of separation between church and state. I appreciate and share Professor Bateman's dismay at simplistic conceptions of what it is to be human, and I think that a metric of rationality for human motivations is as dubious, not to say absurd, as a money metric for human valuations. But, if I understand him correctly, I don't think I am for the revolution he seeks in political economy.

\section{References}

Boyd, R., H. Gintis, and S. Bowles. 2010. Coordinated Punishment of Defectors Sustains Cooperation and Can Proliferate When Rare. Science 328:617-20.

Burkert, Walter. 1996. Creation of the Sacred: Tracks of Biology in Early Religions. Cambridge: Harvard University Press.

Chernyshevsky, Nikolai. [1863] 1989. What Is to Be Done? Translated by Michael R. Katz. Ithaca: Cornell University Press.

Dostoevsky, Fyodor. [1863] 2004. Notes from Underground. Translated by Michael R. Katz. New York: Alfred A. Knopf.

Dubreuil, Benoit. 2008. Strong Reciprocity and the Emergence of Large-Scale Societies. Philosophy of the Social Sciences 38.2:192-210. 
418 History of Political Economy 43:2 (2011)

Kant, Immanuel. [1788] 1997. Critique of Practical Reason. Translated by Mary Gregor. Cambridge: Cambridge University Press.

Nietzsche, Friedrich. [1887] 1989. On the Genealogy of Morals. Translated by Walter Kaufmann and R. J. Hollingdale. New York: Vintage.

Smith, Barbara Herrnstein. 2009. Natural Reflections: Human Cognition at the Nexus of Science and Religion. New Haven: Yale University Press. 